\title{
Peran Guru terhadap Aspek Perkembangan Bahasa Anak Usia Dini
}

\author{
Anna Wahyuni Arifin \\ Jurusan PG-PAUD Universitas Negeri Gorontalo \\ anawahyuniarifin@gmail.com
}

\section{Info Artikel \\ Sejarah Artikel: \\ Diterima (April) (2019) \\ Disetujui (Mei) (2019) \\ Dipublikasikan (Juli) (2019)}

Keywords:

the role of the teacher, language development, early childhood

\begin{abstract}
Abstrak
Permasalahan dalam penelitian ini yaitu peran guru terhadap perkembangan bahasa pada anak di TK Mekar desa Hulawa Kec. Talaga Kab. Gorontalo masih kurang optimal. Tujuan dari penelitian ini yaitu mengetahui peran guru dalam mengembangkan aspek perkembangan bahasa anak. Metode yang digunakan dalam penelitian ini yaitu metode kualitatif. Hasilnya yaitu guru di sekolah tersebut tidak melaksanakan perannya secara optimal, guru belum memaksimalkan keterlibatan anak-anak dalam proses pembelajaran. Dalam proses pembelajaran guru hanya menerapkan metode menulis dan penyerahan materi saja. Guru tidak menerapkan metode yang bisa melatih aspek perkembangan bahasa anak seperti metode bercerita, bernyanyi, Tanya jawab atau berkomunikasi dengan anak lainnya secara langsung, sehingganya anak menjadi merasa bosan dan malas mengikuti pelajarannya dan menjadikan aspek perkembangan bahasa anak tidak berkembang dengan baik. Kesimpulannya, guru sebagai pendidik harus lebih mengoptimalkan perannya dalam mengembangkan aspek-aspek perkembangan anak karena guru sangat berperan penting dalam membantu perkembangan peserta didik untuk mewujudkan tujuan hidupnya secara optimal.
\end{abstract}

\begin{abstract}
The problem in this study is the role of the teacher in the development of children's language in kindergarten blooming Hulawa village Talaga district gor Gorontalo district is still les than optimal. The purpose of this study is to determine the teacher's role in developing aspects of children's language development. The method used in this study is a qualitative method. The result is that teachers in these schools do not carry out their roles optimally, teachers have not yet maximized the involvement of children in the learning process. In the learning process the teacher only applies writing and submission of material. The teacher does not apply methods that can train aspects of children's language development such as the method of telling stories, singing, answering questions or communicating with other children directly, so that children become bored and lazy in following their lessons and make aspects of children's language development not well developed. In conclusion, the teacher as an aducator must further optimize his role in developing aspects of child development because the teacher plays an important role in helping students develop to realize their life goals optimally.
\end{abstract}




\section{Pendahuluan}

Pendidikan anak usia dini adalah salah satu jenjang pendidikan sebelum pendididkan dasar yang merupakan suatu upaya pembinaan yang ditujukan bagi anak sejak lahir sampai dengan usia enam tahun yang dilakukan melalui pemberian rangsangan pendidikan untuk membantu perkembangan jasmani dan rohani anak agar anak memiliki kesiapan dalam memasuki jenjang pendidikan lebih lanjut (UU Sisdikans No. 20 th 2003).

Pendidikan mempunyai peran penting dalam menentukan perkembangannya, salah satunya perkembangan bahasa. Keterampilan bahasa juga penting dalam rangka pembentukan konsep, informasi dan pecahan masalah. Jadi dengan bahasa manusia dapat berkomunikasi dan berinteraksi dengan orang lain baik itu secara lisan, tulisan, simbol, bahasa tubuh dan lain sebagainya. Kemudian dengan bahasa manusia dapat memahami dirinya sendiri, memahami orang lain, alam semesta, sang maha pencipta, serta dapat memposisikan dirinya sebagai makhluk yang memiliki budaya.

Bahasa mempermudah anak mengeluarkan ide-ide dan pendapatnya sehingga terjalin komunikasi serta sosialisasi terhadap lingkungannya. Mengeluarkan pemakaian perkembangan bahasa pada anak dipengaruhi oleh meningkatnya usia anak. Semakin anak bertambah umur, maka akan semakin banyak kosakata yang dikuasai dan semakin jelas pelafalan atau pengucapat katanya.

Guru sangat berperan penting dalam membantu perkembangan peserta didik untuk mewujudkan tujuan hidupnya secara optimal. Kenyataan ini muncul karena manusia makhluk lemah sejak lahir bahkan pada saat meninggal. Semua itu menunjukkan bahwa setiap orang membutuhkan orang lain dalam perkembangannya demikian peserta didik.

Anak usia dini adalah individu yang sedang menjalani proses pertumbuhan dan perkembangan yang pesat dan sangat fundamental bagi proses perkembangan selanjutnya. Rasa ingin tahu yang kuat terhadap segala sesuatu merupakan cirri yang menonjol pada anak usia dini. Pada anak usia ini memiliki sikap berpetualang yang begitu kuat, banyak memperhatikan, membicarakan, atau bertanya tentang berbagai macam hal. 
Menurut (Morrison, 2012: 223) kemampuan berbahasa pada anak perkembangan selama masa prasekolah, Morrison mengatakan bahwa kosakata, jumlah kata, yang diketahui akan terus berkembang oleh karena itu peran guru dalam pengembangan bahasa pada anak usia dini sangatlah penting. Selama masa prasekolah perkembangan bahasa anak beragam dan komperatif, menunjukkan jangkauan pembelajaran sangat mengesankan lagi adalah bahwa anak belajar intuitif tanpa banyak instrusi, aturan bahasa yang diterapkan pada kata dan frasa yang mereka gunakan. Untuk pengembangan bahasa pada anak dapat dilakukan dengan banyak latihan seperti bernyanyi, membaca, berbicara atau berkomunikasi dengan anak secara langsung dan dengarkan lagu yang sesuai dengan tema. Kegiatan bernyanyi merupakan salah satu metode pembelajaran yang bertujuan untuk memotivasi anak pada saat belajar. Peran guru menurut (Nielsen, 2006: 15) adalah merencanakan dan menyiapkan lingkungan belajar. Karena anak usia dini belajar melalui permainan, penting untuk menyediakan material dan perlengkapan yang diperlukan untuk aktivitas permainan penuh makna yang mendukung perkembangan kecerdasan ganda.

Kegiatan belajar mengajar akan berjalan dengan baik dan mencapai tujuan yang diharapkan bila anak terlibat dalam proses pembelajaran. Yang dimaksud dengan terlibat dalam proses pembelajaran bahwa anak dapat menyampaikan pikiran dan perasaan secara langsung. Dalam proses pembelajaran peserta didik sangat penting dalam mendorong proses yang sangat menarik atau menggunakan metode pembelajaran misalnya bernyanyi, bercerita, Tanya jawab, dan yang dapat melibatkan anak secara langsung dalam perkembangan bahasanya.

Tujuan dari penelitian ini adalah agar dapat meneliti dan mengetahui proses pembelajaran yang terjadi di sekolah tersebut, dan ditemukan pada proses pembelajarannya dalam hal mengembangkan aspek perkembangan bahasa anak guru tidak melaksanakan perannya dengan baik. Guru tidak memaksimalkan keterlibatan anak-anak dalam proses pembelajaran, guru tidak menerapkan metode-metode yang dapat melatih aspek perkembangan bahasa anak. Guru hanya menerapkan metode menulis saja atau penyerahan materi tanpa menerapkan metode-metode yang dapat melatih kemampuan berbicara atau berbahasa anak seperti metode bercerita, bercakap-cakap, Tanya jawab dan sebagainya. 
(Fadillah, 2012: 161) menyatakan bahwa metode pembelajaran adalah suatu cara atau sistem yang digunakan dalam pembelajaran yang bertujuan agar anak didik dapat mengetahui, memahami, mempergunakan dan menguasai bahan pelajaran tertentu. Melalui sebuah metode pembelajaran seorang guru dapat merancang pembelajaran untuk dapat mengoptimalkan seluruh aspek perkembangan anak (perkembangan bahasa) salah satunya adalah dengan metode bercakap-cakap. Didalam percakapan ditentukan sebuah tema agar percakapan yang dilakukan dapat terarah dengan baik dan tidak jauh dari kehidupan anak.

\section{Metode Penelitian}

Jenis Penelitian

Penelitian ini menggunakan metode penelitian kualitatif. Metode penelitian kualitatif adalah sebuah metode riset yang sifatnya deskriptif, menggunakan analisis, mengacu pada data, memanfaatkan teori yang ada sebagai bahan pendukung, serta menghasilkan suatu teori. Proses dan makna (perspektif subjek) lebih di tonjolkan dalam pendekatan kualitatif. Landasan teori dimanfaatkan sebagai pemandu agar fokus penelitian sesuai dengan fakta di lapangan. Selain itu landasan teori juga bermanfaat untuk memberikan gambaran umum tentang latar penelitian dan sebagai bahan pembahasan hasil penelitian.

Menurut (Moleong, 2006: 6) metode penelitian kualitatif adalah suatu riset yang bermaksud untuk memahami fenomena yang dialami oleh subjek penelitian. Misalnya perilaku, persepsi, motivasi, tindakan, dan lain-lain secara holistic, dan dengan cara deskripsi dalam bentuk kata-kata dan bahasa pada suatu konteks khusus yang alamiah dan dengan memanfaatkan berbagai metode alamiah. Menurut (Sugiyono, 2009: 15) metode penelitian kualitatif adalah penelitian yang digunakan untuk menyelidiki, menemukan, menggambarkan, dan menjelaskan kualitas atau keistimewaan dari pengaruh sosial yang tidak dapat dijelaskan, diukur atau digambarkan melalui pendekatan kuantitatif.

Waktu dan Tempat Penelitian

Penelitian di lakukan pada bulan oktober-november 2019 di TK Mekar Desa Hulawa Kec. Talaga Kab. Gorontalo yang berjumlah 35 anak, pada kelompok A 15 anak dan kelompok B 20 anak. Teknik pengumpulan data dalam penelitian ini yaitu 
menganalisis proses pembelajaran di sekolah tersebut dan juga mengambil beberapa gambar atau dokumentasi.

Subjek Penelitian

Penelitian ini dilakukan pada bulan oktober-november 2019, di TK Mekar Desa Hulawa Kec. Talaga Kab. Gorontalo.

\section{Prosedur}

Penelitian ini menggunakan tipe deskriptif. Dilakukan dengan menganalisis proses pembelajaran di sekolah yang di teliti, cara guru dalam memberikan pelajaran atau metode apa yang guru terapkan dalam proses pembelajaran terutama untuk mengembangkan aspek perkembangan bahasa anak di sekolah tersebut.

Data, Intrumen, dan Teknik Pengumpulan Data

Pengumpulan data pada penelitian ini yaitu dengan melakukan observasi dan menganalisis proses pembelajaran disekolah tersebut dan juga mengambil beberapa gambar atau dokumentasi.

Teknik Analisis Data

Penelitian ini bertujuan agar guru lebih memperhatikan lagi caranya dalam memberikan stimulasi pendidikan kepada anak terutama dalam aspek perkembangan bahasanya. Proses analisis data dilakukan selama penelitian di TK Mekar dengan cara menganalisis proses pembelajarannya kemudian mengambil kesimpulan.

\section{Hasil Penelitian dan Diskusi}

Berdasarkan hasil penelitian yang di lakukan di TK Mekar, guru kurang berperan dalam mengembangkan aspek kemampuan berbahasa anak. Peran guru sangat dibutuhkan untuk mendukung terciptanya suasana belajar mengajar yang menyenangkan aktif dan memungkinkan anak berprestasi secara maksimal. Guru mempunyai peran-peran untuk membagikan pengetahuan dan suasana pembelajaran menjadi menyenangkan dan efektif (Triatna, 2008: 22). Guru harus memahami betul peranannya dalam proses belajar mengajar yang bersifat majemuk, artinya peran guru tidak hanya satu tetapi lebih dari satu. Bahkan peran guru tidak dapat digantikan dengan sarana pendidikan. Bagaimanapun baiknya sarana pendidikan apabila guru 
tidak melaksanakan tugasnya dengan baik maka hasil pembelajarannya juga tidak akan memuaskan.

Guru belum memaksimalkan keterlibatan anak-anak dalam proses pembelajaran. Sebagaimana dijelaskan bahwa proses pembelajaran pada hakekatnya untuk mengembangkan aktivitas dan kreativitas peserta didik melalui berbagai interaksi dan pengalaman belajar. Keaktifan belajar siswa merupakan unsur dasar yang penting bagi keberhasilan proses pembelajaran. Keaktifan adalah kegiatan yang bersifat fisik maupun mental, yaitu berbuat dan berfikir sebagai suatu rangkaian yang tidak dapat dipisahkan (Sardiman, 2001: 98). (Sudjana, 2004: 61) juga menyatakan bahwa keaktifan siswa dapat dilihat dalam hal : 1) turut serta dalam mengerjakan tugas belajarnya; 2) terlibat dalam pemecahan masalah; 3) bertanya kepada siswa lain atau guru apabila tidak memahami persoalan yang di hadapinya; 4) berusaha mencari berbagai informasi yang diperlukan untuk pemecahan masalah.

Dalam proses pembelajaran guru hanya menerapkan metode menulis dan penyerahan materi saja, guru tidak menerapkan metode yang dapat mengembangkan aspek perkembangan bahasa anak seperti metode bercakap-cakap, bercerita, bernyanyi, Tanya jawab atau berkomunikasi dengan anak lain secara langsung. Seperti menurut (Fadillah, 2012: 161) menyatakan bahwa metode pembelajaran adalah suatu cara atau sistem yang digunakan dalam pembelajaran yang bertujuan agar anak didik dapat mengetahui, memahami, mempergunakan dan menguasai bahan pelajaran tertentu. Melalui sebuah metode pembelajaran seorang guru dapat merancang pembelajaran untuk dapat mengoptimalkan seluruh aspek perkembangan anak (perkembangan bahasa) salah satunya adalah dengan metode bercakap-cakap. Didalam percakapan ditentukan sebuah tema agar percakapan yang dilakukan dapat terarah dengan baik dan tidak jauh dari kehidupan anak. Menurut (Isjoni, 2011: 90) metode bercakap-cakap mempunyai makna penting bagi perkembangan anak karena bercakap-cakap dapat meningkatkan keterampilan berkomunikasi dengan orang lain dan meningkatkan keterampilan dalam melakukan kegiatan bersama.

Kurangnya anak diberi kesempatan untuk mengungkapkan alasan atau ketidaksetujuan yang mereka inginkan, kurangnya anak mendengarkan cerita atau dongeng yang mereka dengar. Sedangkan tingkat pencapaian yang harus dicapai pada anak usia TK adalah seperti : (1) memahami cerita yang dibacakan, (2) menyebutkan 
kata sifat (nakal, pelit, baik hati, berani, baik, jelek, dsb), (3) menyebutkan nama diri, nama orang tua, jenis kelamin, alamat rumah secara sederhana, (4) memberikan alasan yang tidak diinginkan atau ketidaksetujuan, (5) mengulang kalimat sederhana, dan masih banyak indikator-indikator tingkat pencapaian perkembangan bahasa yang harus dicapai anak usia TK. Mengingat kemampuan bahasa lisan merupakan hal yang sangat penting untuk dikembangkan di usia TK, merupakan waktu yang tepat bagi anak untuk menguasai bahasa kedua dengan lancar dan sesuai dengan pembicara asli (Ladefoged, 1969: 25).

Perkembangan bahasa untuk anak usia dini meliputi empat pengembangan yaitu mendengarkan, berbicara, membaca dan menulis. Pengembangan tersebut harus dilakukan seimbang agar memperoleh pengembangan membaca dan menulis yang optimal. Perkembangan bahasa untuk anak taman kanak-kanak berdasarkan acuan standar pendidikan anak usia dini no. 58 tahun 2009, mengembangkan tiga aspek yaitu menerima bahasa, mengungkapkan bahasa dan keaksaraan.

\section{Simpulan}

Berdasarkan hasil kajian yang telah dipaparkan, disimpulkan betapa pentingnya kemampuan guru dalam menciptakan stimulasi-stimulasi kebahasaan. Lebih rinci lagi khusus untuk menstimulasi kemampuan berbicara, (Yawkey, 1981) meramu secara detail stimulasi apa saja yang bisa dilakukan untuk mengembangkan kemampuan bahasa ekspresif tersebut. Poin yang dipaparkan untuk menstimulasi kemampuan berbicara diantaranya tentang (1)pengembangan kefasihan berbahasa, (2) pengembangan kemampuan sintaksis, (3) pengembangan penguasaan kosa kata, (4) pengembangan pengintegrasian kemampuan bahasa dalam kehidupan sehari-hari, (5) kemampuan mengekspresikan diri sendiri.

Di sekolah TK Mekar Desa Hulawa Kec. Talaga Kab. Gorontalo, guru belum memaksimalkan perannya sebagai pendidik yang mampu menstimulasi apek-aspek perkembangan pada anak usia dini terutama pada aspek perkembangan bahasanya. Guru tidak memaksimalkan keterlibatan anak-anak dalam proses pembelajaran. Untuk langkah selanjutnya di harapkan kepada guru atau pendidik agar lebih memperhatikan dan mengoptimalkan perannya untuk menstimulus aspek- aspek perkembangan anak terutama pasa aspek perkembangan bahasa anak. 


\section{Daftar Pustaka}

Suyadi, Maulidya Ulfah. 2016. Konsep Dasar Paud. Bandung: PT Remaja Rosdakarya

Rini. (2017). Peran guru dalam pengembangan bahasa lisan pada anak usia 5-6 tahun. Journal of Childhood Education, 2017.

Endah, Silawati. (2010). Stimulasi guru pada pembelajaran bahasa anak usia dini.

Willdan AmzamStiawan (2019). Stimulasi guru terhadap perkembangan bahasa anak TK. Diakses tanggal 22 oktober 2019 dari https://www.kompasiana.com 